\title{
List of Tables, Figures, and Photographs
}

Tables

3.I. Violence Worker Sample 36

3.2. Facilitator Sample $\quad 37$

I I.I. Accounting for Atrocities 196

I I.2. Moral Reckoning about Torture 197

I2.I. Burnout Reactions 2 2I6

Figures

3.I. Known Torturers and Killers 40

3.2. Denounced by Colleagues or Family 4I

3.3. Network Analysis 42

3.4. Violence Committed 43

Photographs

Families of disappeared victims gather at São Paulo’s Praça de Sé Cathedral to remember and challenge violence

Torture victim on a "parrot's perch," police station, Pôrto Alegre, Brazil

Cambodian version of the full-body water torture known in Brazil as "the submarine" 
The "rational" torturer interrogates as water drips for hours on his victim's head, leaving no visible marks

Poor people slaughtered in 1993 in their Vigário Geral slum by police-linked death squads

Bones of military-period assassination victims unearthed from a shallow grave in Dom Bôsco Cemetery, Perús, São Paulo 